\title{
MENELISIK SIASAT CERITA DIGITAL REALITY PADA FILM READY PLAYER ONE?
}

\section{Probing Digital Reality Story Tactics in the Film Ready Player One?}

\author{
Jokhanan Kristiyono $^{1}$, Hernani Sirikit ${ }^{2}$ \\ ${ }^{1)}$ 2)Ilmu Komunikasi/Sekolah Tinggi Ilmu Komunikasi-Almamater Wartawan Surabaya \\ 1) 2)Jalan Nginden Intan Timur 1/18, Surabaya
}

Diterima 14 Agustus 2019 / Disetujui 20 September 2019

\begin{abstract}
This study aims to find out how factual and digital reality are depicted in film.Castells' theory on new media is taken for the base theory, subjectivity-identity and power and knowledge by Foucault. Narrative analysis by Lacey is applied to seek answer for the research problem. The advancement of Communication Technology has enabled human beings to have freedom in imagination and make it real. Digital technology and virtual realm are enriched with emerging faked realities and identities. Film, becomes a platform for practising this kind of freedom, making fantasy feels like reality. Film Ready Player One? directed by Steven Spielberg depicts real and virtual world. This study aims to elaborate how real life and digital life are narrated and described in this film. A new identity created in The OASIS, the digital world that a place where mankind escape from reality. Units to be analysed in eight structures of analysis are story, plot, and character. Concludesis factual reality and digital reality are described well in this film, it even tends to hyper-reality. Moreover, conflict in digital world and in the future (2045) are still the same with problems in the history of mankind.
\end{abstract}

Keywords; Film; Digital reality; Identities; Narrative.

\begin{abstract}
ABSTRAK
Penelitian ini bertujuan mengetahui bagaimana realitas faktual dan realitas digital digambarkan dalam film. Menggunakan teori new media Castells, subjektivitas dan identitas serta power dan knowledge Foucault. Penelitian film ini menggunakan pendekatan deskriptif kualitatif, dengan metode Analisa Naratif Film (Lacey, 2017). Kemajuan teknologi informasi dan komunikasi membuat manusia memiliki keleluasaan dalam berimajinasi dan merealisasikannya. Teknologi digital dan alam virtual semakin diperkaya dengan munculnya realitas dan identitas semu. Film, sebagai salah satu medium komunikasi massa, merupakan wadah kebebasan berimajinasi. Film Ready Player One?.Film besutan sutradara Steven Spielberg menggambarkan pergesekan antara dunia nyata dan dunia digital. Film ini menunjukkan kehidupan masyarakat moderen_pada tahun 2045, dengan adanya perkembangan teknologi yang luar biasa. Suatu piranti yang mengubah manusia menjadi sangat tergantung dengan teknologi. Teknologi informasi dan komunikasi yang menciptakan dunia baru yaitu dunia digital. OASIS, dunia tempat pelarian manusia modern dan menciptakan identitas baru yaitu identitas virtual. Masyarakat informasi yang menciptakan realitas digital. Unit analisis story, plot, dan karakter dianalisis secara naratif dengan delapan struktur. Hasil analisis memberikan jawaban bahwa realitas nyata dan realitas digital digambarkan secara baik dalam film ini, bahkan cenderung berlebihan (hyper-reality). Selain itu, konflik di dunia digital di tahun 2045 tetap sama dengan konflik dalam sejarah manusia.
\end{abstract}

Kata Kunci; Film; Digital Reality; Identitas; Naratif.

*Korespondensi Penulis:

E-mail: jokhanan.k@stikosa-aws.ac.id 


\section{PENDAHULUAN}

Perkembangan teknologi dan komunikasi telah mengubah cara manusia berkomunikasi dan mendapatkan atau menyebarkan informasi. Teknologi komunikasi juga mengubah dan membentuk kehidupan sosial masyarakat yang baru, yang sangat bergantung pada piranti elektronik. Pesan dan informasi disampaikan melalui medium radio, televisi, film, game, foto digital, yang dapat diakses dan terhubung melalui Internet. Teknologi komunikasi digital mendorong imajinasi manusia menembus batas realita, sehingga terciptalah realitas semu -manipulasi atas realitas yang nyata. Fenomena ini menggambarkan bahwa manusia sebagai makhluk sosial dapat bergerak dari dunia nyata masuk ke alam imajinasi dan sebaliknya. Dunia semu atau dunia maya tak hanya terasa tapi benar-benar menjadi nyata. Identitas semu di dunia maya menghadirkan sebuah realitas sosial yang semu pula.

Teknologi komunikasi digital bukan hanya merupakan format atau medium komunikasi, tetapi sudah menjadi elemen penting dalam kehidupan manusia, baik sebagai pribadi maupun sebagai anggota masyarakat. Ini membentuk dunia digital yang baru, yaitu yang disebut sebagai masyarakat berjaringan (network society). Aktivitas masyarakat dalam dimensi baru teknologi digital ini dikenal sebagai aktivitas digital (digital activism). Aktivitas digital digambarkan dengan jelas dalam skema mekanisme perubahan teknologi digital dalam aktivitas sosial oleh Joyce dalam bukunya Digital activism decoded: The new mechanics of change (Joyce, 2010).

Dunia siber dan dunia digital memang memberi ruang dan kesempatan yang luas bagi individu atau kelompok masyarakat untuk mengkonstruksi realita, termasuk mengkonstruksi identitas dirinya. Setiap individu atau kelompok sosial dapat menciptakan identitas di dunia maya, baik yang serupa atau sama dengan identitas aslinya di dunia nyata (fisik), maupun yang berbeda sama sekali dengan kenyataannya. Seseorang, misalnya, dapat mempopulerkan dirinya secara apa adanya (nyata) melalui dunia maya. Seseorang juga dapat mempublikasikan dirinya dengan "identitas semu", identitas yang berbeda dari kenyataanya (Castells, 2011).

Medium informasi dan komunikasi tak hanya berubah secara teknik dan fungsinya, namun juga muatan atau konten pesannya. Terjadinya perubahan sosial, budaya, maupun politik di dunia yang tidak lagi terbatas dan sangat mudah diakses oleh warga dunia, khususnya warga yang terhubung dengan Internet (netizen). Perubahan tersebut sama dramatisnya dengan proses kemajuan teknologi. Kemajuan teknologi dan perubahan sosial budaya dan politik, menyatu dengan harmoni dalam medium komunikasi karya seni, salah satunya karya film.

Film, sebagai salah satu media komunikasi massa yang secara tradisional menggambarkan kondisi realita sosial, juga mengalami transformasi di awal abad 21 ini. Sejak film Avatar (2009) yang dianggap pembaharu dalam genre-nya, imajinasi tanpa batas yang dimiliki manusia tersalurkan dan terwadahi dengan sempurna melalui medium film. Salah satu contohnya adalah film Ready Player One?arahan sutradara Steven Spielberg yang menjadi obyek penelitian ini. Film produksi tahun 2018 ini dikategorikan sebagai film fiksi, lebih tepatnya fiksi ilmiah (sci-fi), karena kisahnya khayalan, diadaptasi dari novel karya Ernest Cline, yang bersetting atau berlatar dunia digital (dunia maya). Bahkan, karakter dalam film juga gabungan antara sang tokoh sebagai manusia nyata dan dia sebagai manusia avatar (sosok pengganti diri seseorang di dunia maya).

Ready Player One? mengambil latar waktu masa depan, yaitu tahun 2045. Realitas dan fenomena sosial yang digambarkan dalam film tumpang tindih antara yang nyata dan maya. Para karakter dalam film hidup di dua dunia, yaitu dunia nyata dan dunia imajinasi (virtual reality). Sebagaimana filmfilm Spielberg terdahulu (ET, AI, Jurassic Park, dan sebagainya), film ini menonjol di segi teknik film, khususnya efek visual. Dalam alur cerita atau plot, sang tokoh dapat berpindah tempat dalam dunia yang tak hanya berbeda waktu (mengalami flash back dan flash forward) namun juga berbeda alam (nyata dan maya). Selain menggambarkan 
perlawanan masyarakat kelas bawah melawan dominasi korporasi (elit yang berkuasa), film juga menggambarkan persoalan subyektivitas atau identitas diri masyarakat pascamodern, khususnya manusia tahun 2045, yang diselimuti piranti serba digital. Dalam kebosanan menjalani hidupnya, sang tokoh (Wade Watts) dapat sewaktu-waktu escape atau melarikan diri ke dunia maya dan menjadi sosok yang lain.

Aktivitas digital pada masyarakat kontemporer atau masyarakat informasi seperti digambarkan dalam masyarakat tahun 2045 di film ini, memungkinkan terbangunnya realitas sosial yang semu, termasuk terbentuknya identitas digital (Castells, 2011). Gerakan atau aktivitas digital (digital activism) ini muncul karena adanya tujuan bersama yaitu mempertahankan ruang publik (public sphere) seperti yang disampaikan oleh Habermas (Lubenow, 2012).

Setiap karakter dalam film ini memiliki dua identitas, yaitu identitas nyata dan identitas semu. Identitas atau jati diri merupakan pengenalan terhadap makna dan pengalaman seseorang. Di era pascamodern ini, identitas atau jati diri menjadi persoalan utama warga dunia. Seperti dikatakan oleh Edward McGushin, manusia sekarang hidup dalam dunia yang mengalami percepatan teknologi yang luar biasa, diwarnai manipulasi atas mood (suasana hati) yang bersifat kimiawi, bahkan rekayasa genetika; maka pertanyaannya sekarang adalah "siapa diri kita sebenarnya?" (McGushin, 2011)

Foucault juga membahas persoalan identitas dan subjektivitas ini secara khusus, seperti ditulis oleh McGushin dalam artikelnya "Foucault Theory and Practice of Subjectivity" (Taylor, 2014):

Subjectivity in this sense is the real basis of the self as both agent and object. In other words, Foucault argues that the self or subject is not a self-standing being, some sort of essence or substance, that exists within us whether we look for it or not (1996b). It is brought into existence as the upshot of some form of relational activity. What is more, subjectivity, as a dynamic, active relationship, can

take on a number of different forms.

Dalam pandangan Foucault, subjektivitas merupakan pondasi diri, baik sebagai agen atau obyek. Diri atau subyek bukanlah sosok yang berdiri sendiri, melainkan terbentuk karena adanya aktivitas relasional. Dengan kata lain, jati diri bukanlah semata-mata "being" namun "becoming", bukan "siapa" tetapi "menjadi apa". Ini sejalan dengan konsep Giddens tentang identitas, yaitu bahwa identitas adalah sumber makna bagi setiap orang, dan identitas dibangun melalui sebuah proses yang panjang (Bendle, 2002). Teori ini sangat tepat dalam mengupas karakter dalam film Ready Player One?, mengingat karakteristik para tokoh dalam film yang memang tidak biasa.

Selain berkaitan dengan konsep subjektivitas, obyek penelitian juga menarik ditinjau dari sudut pandang relasi kuasa. Seperti kata Foucault, kekuasaan dan pengetahuan itu tak terpisahkan. "Knowledge is the exercise of power, and power is the function of knowledge."(McGushin, 2011). Pengetahuan adalah latihan bagi kekuasaan, dan kekuasaan adalah fungsi dari pengetahuan. Film yang diteliti memiliki kedua unsur tersebut, kekuasaan dan pengetahuan, dimana tokoh yang memiliki pengetahuan tentang misteri tiga kunci, akan memeroleh kekuasaan. Di lain pihak, tokoh yang memiliki kekuasaan akan menggunakan kuasanya untuk memeroleh pengetahuan tersebut. Perlombaan menemukan tiga kunci ini mengawali serangkaian aksi perlawanan terhadap kekuasaan.

Dalam kaitan dengan film ini, budaya yang terbangun adalah budaya pascamodern, dimana teknologi menjadi determinasi perilaku manusia. Artinya, segala aspek kehidupan manusia, baik domestik maupun publik, sangat ditentukan oleh kecanggihan teknologi. Teknologi media komunikasi membangun identitas baru manusia, digambarkan dengan baik di film ini. Castells mengingatkan, beberapa individu mungkin bisa memiliki sejumlah identitas, tanpa menyadari bahwa beragam identitas seperti itu dapat menjadi sumber permasalahan. Kontradiksi akan terjadi, baik dalam 
representasi diri maupun dalam interaksi sosial. (Castells, 2011b).

Terdapat tiga penelitian terdahulu yang dapat menjadi rujukan pada penelitian ini. Pertama penelitian yang berjudul Counter-hegemony: grassroots use of the Internet to save dialects in China (Luqiu, 2018) tentang bagaimana Internet digunakan untuk menciptakan kekuatan kontrahegemoni (counter-hegemony) akar rumput. Namun, bagaimana individu dapat mempengaruhi perubahan pada pengembangan kebijakan bahasa, terutama dalam konteks pada negara Cina. Studi ini menganalisis tiga bentuk kegiatan online yang berbeda - konten yang dihasilkan sendiri, interaksi, dan diskusi - untuk menunjukkan bagaimana Internet memberdayakan individu dan menciptakan ruang publik virtual untuk partisipasi publik dan meningkatkan kesadaran publik.

Ditemukan bahwa Internet memungkinkan warga untuk berpartisipasi dalam pembuatan wacana kontra-hegemoni online. Konten yang didemokratisasi dan proses partisipasi ini memberikan daya tawar pada akar rumput terhadap wacana hegemoni. Studi ini juga membahas tantangan dan keterbatasan peran individu dalam mengubah kebijakan bahasa di negara-negara di mana warga negara memiliki hak politik dan kewarganegaraan yang terbatas.

Perbedaan dengan penelitian ini adalah medium yang dijadikan obyek penelitiannya. Artikel ini menggunakan media Film yang berjudul Ready Player One?sebagai obyek penelitian, sedangkan interaksi dan dialektika yang terjadi hampir sama yaitu terciptakanya wacana atau diskursus ruang publik virtual.

Kedua terkait mesin kapitalisme dan revolusi molekuler yang berjudul Dividual Revolution: What Can Philosophy Do in the Digital Present? (Nony, 2019), penulis melakukan penelitian tentang hubungan divisi dengan revolusi dan melibatkan modalitas partisi dan ekstraksi yang digunakan dalam sistem dominasi kapitalis. Penulis menyoroti bagaimana Raunig menghadapi operasi kapitalisme yang mekanis dan memposisikan konsep pembagian seperti yang berkembang dalam Skolastik awal, yaitu, sebelum munculnya kapitalisme. Nilai dari pendekatan ini adalah untuk memikirkan tentang implementasi struktur kapitalis perampasan, dan ekstraksi.

Marxisme muncul untuk berteori mereka dan menyatakan bahwa kegagalan dan janji revolusi telah menciptakan paradigma modern untuk mengatasi perjuangan politik dari masa kita, yang berulang secara berulang untuk menantang batas umat manusia.

Kapitalis pada era digital tergambar sama dengan riset ini, mulai dari struktur ekonomi di dunia virtual atau digital hingga terjadinya perampasan dan ekstrasi di dunia digital dan dunia nyata. Perbedaan adalah selain medium yang dijadikan obyek penelitiannya, struktur kapitalis dominasi dan hegemoni ekonomi ditunjukkan sangat jelas pada film Ready Player One? sebagai sebuah pesan kepada masyarakat modern saat ini dalam media komunikasi berformat Film.

Penelitian ketiga berjudul Staying with the paradox of Avatar: Decolonising sciencelfiction (Cettl, 2019), peneliti melihat secara mendalam tentang film sci-fi Avatar karya sutradara James Cameron (2009). Film ini dapat dikaji sebagai fenomena yang layak diteliti dalam konteks yang lebih luas dari ekologi, dan berpendapat bahwa itu paling baik dipahami secara paradoks. Pada tingkat narasi menengah, spesifik binari digambarkan secara hierarki dalam film ini, dan penggambaran seperti itu secara tidak sadar dilemahkan: antara teknologi dan organik, ilmu pengetahuan Barat dan animisme adat, teknologi Barat dan praktik perdukunan.

Peneliti melihat menggerogoti fungsifungsi biner ini sebagai isyarat dekolonisasi, dengan maksud mempertanyakan hierarki penjajahan antara hal yang telah dilegitimasi sebagai sains yang layak dan hal yang diberhentikan sebagai takhayul asli. Dekolonisasi epistemologi historis semacam itu merupakan kunci penting dalam memikirkan kembali ekologi politik antara manusia dan non-manusia, tetapi juga antara berbagai manusia dalam dimensi politik kontemporer. Peneliti mengusulkan bahwa dalam mendekati ekologi populer yang kritis, masyarakat dapat 'bertahan dengan paradoks' dan dengan cara ini mendekolonisasi sains atau fiksi. 
Paradoks ekologi dan fenomenologi di film Avatar garapan James Cameran yang dikupas dan dikaji oleh penulis ini menggambarkan 2 dunia yang berbeda dalam ruang dan waktu yang sama, bagaimana manusia bisa menggerakkan dan menjalankan avatarnya secara fisik di dunia nyata. Perbedaan dari film Ready Player One?yang diteliti pada tulisan ini adalah avatar yang digerakkan oleh tokoh (Wade Watts) yaitu Perzival berada di dunia yang berbeda dan di ruang yang berbeda. Ruang dan dunia digital di virtual itu menjadi realitas virtual atau Digital Reality yang menjadi kajian dan topik pada tulisan ini.

Dengan latar belakang perkembangan teknologi siber dan digital yang diterapkan di dunia seni, khususnya film, serta konten pesan tentang perlawanan sosial dalam film Ready Player One?, peneliti tertarik untuk menganalisis secara lebih dalam film ini. Dengan menggunakan metode analisis naratif, peneliti akan mendeskripsikan secara naratif pesan sosial film ini.

Rumusan masalah yang diangkat yaitu: "Bagaimana realitas sosial yang nyata dan yang digital digambarkan dalam film Ready Player One?"

Penelitian ini bertujuan untuk mengungkapkan penggambaran secara detil realitas digital dalam film Ready Player One?, sebuah film fiksi ilmiah karya sutradara Steven Spielberg. Manfaat yang didapat dari hasil penelitian ini secara teoritis diharapkan dapat memperkaya kajian film dengan sudut pandang teori media baru Manuel Castells, teori subjektivitas serta power and knowledge Michel Foucault, menggunakan metode analisis naratif (Ida, 2014). Manfaat penelitian secara praktis diharapakan hasil penelitian ini dapat memberi masukan yang berharga bagi para sineas Indonesia untuk mempertimbangkan digunakannya secara berani teknik digital dalam produksi film, serta dipilihnya tematema baru semacam dunia realita digital.

\section{METODE PENELITIAN}

Penelitian film ini menggunakan pendekatan deskriptif kualitatif, dengan metode Analisa Naratif Film(Lacey, 2017). Teknik naratif sebagai metode analisis ini berguna untuk melihat keseluruhan film sebagai sebuah bentuk komunikasi massa dengan karakter yang khas, yang tidak dimiliki oleh program televisi dan audio visual documenter(Ida, 2014).Sebagaimana program audio visual dokumenter dan program televisi, film memiliki dua unsur, yaitu gambar dan suara (audio visual) dan cerita (narasi). Namun dalam medium film, ada aspek lain yang hanya dapat ditangkap melalui teknologi layar lebar (bioskop) khususnya dalam aspek teknologi audio dan narasi panjang.

Narasi adalah keseluruhan cerita (story) dan gaya bertutur (alur atau plot). Peneliti menambahkan anasir karakter sebagai unit analisis, mengingat tokohnya merupakan karakter yang tidak biasa, yaitu yang hidup di dunia nyata dan dunia digital, yang disoroti oleh Foucault dalam teorinya mengenai subjectivitas dan identitas. Metode penelitian analisis naratif film pada dasarnya mengikuti standar metode penelitian analisis isi kualitatif strukturalisme.

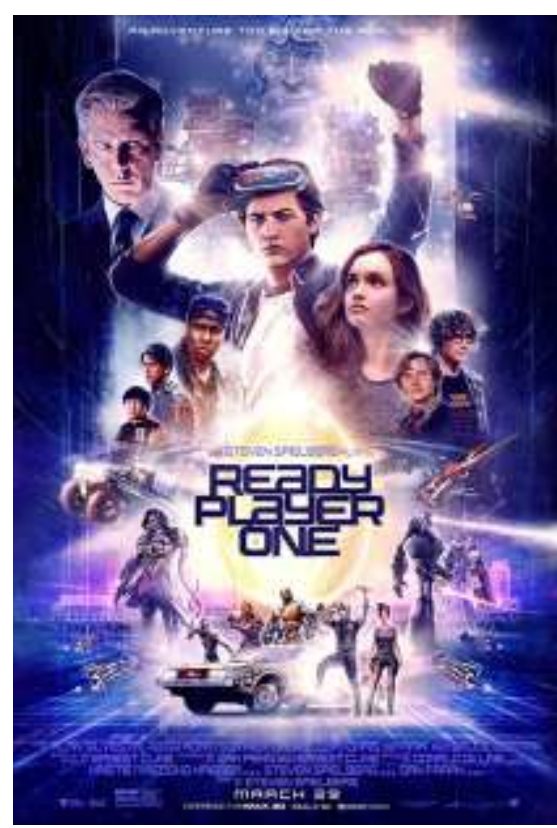

Gambar 1. Poster Film Ready Player One? (Sumber: www.warnerbros.com)

Film ini diproduksi tahun 2018, diproduseri oleh Bruce Berman dan Steven Spielberg (bertindak pula sebagai sutradara), dengan rumah produksi Warner Bros. 
Skenario diadaptasi dari Novel Fiksi berjudul Ready Player One karya Ernest Cline. Film berdurasi 2 Jam 20 Menit dengan pemeran film antara lain: Ben Mendelsohn, Simon Pegg, Mark Rylance, Lena Waithe, Win Morisaki, Tye Sheridan, Olivia Cooke, dan Philip Zhao.

Latar (film setting) diarahkan pada tahun 2040, dunia telah dilanda krisis energi dengan menipisnya bahan bakar fosil dan konsekuensi yang diterima dari pemanasan global (global warming). Kelebihan penduduk salah satu permasalahan juga menyebabkan kendala sosial yang meluas hingga stagnasi ekonomi. Untuk menghindari kemunduran yang dihadapi dunia mereka, orang-orang beralih ke OASIS, sebuah simulator realitas virtual yang dapat diakses oleh pemain yang menggunakan pelindung dan teknologi haptic (mengaplikasikan sensasi sentuhan ke dalam interaksi manusia dengan komputer. Haptic berasal dari bahasa Yunani haptesthai yang artinya 'menyentuh') seperti sarung tangan.

Ini berfungsi baik sebagai Massively Multiplayer Online Role-Playing Game (MMORPG) dan sebagai dunia virtual. OASIS itu diciptakan oleh James Donovan Halliday, pendiri Gregarious Simulation Systems (GSS, dulunya bernama Gregarious Games), dan ketika dia meninggal, telah mengumumkan dalam surat wasiatnya kepada publik bahwa Halliday telah meninggalkan telur Paskah di dalam OASIS.Orang pertama yang menemukan telur ituakan mewarisi seluruh kekayaannya, kepemilikan perusahaannya serta OASIS itu sendiri, yang bernilai triliunan. Kisah ini mengikuti petualangan Wade Watts, dimulai sekitar lima tahun setelah pengumuman yaitu pada tahun 2045, ketika ia menemukan salah satu dari tiga kunci yang membuka tiga gerbang berturut-turut menuju harta.

Alur cerita (plot film) diawali dengan Wade Watts seorang remaja yang tinggal bersama bibinya di Kota Oklahoma di "Stack"yaitu daerah kumuh pinggiran kota dengan termpat tinggal container berkas yang ditumpuk-tumpuk. Stack adalah sebuah distrik yang dilanda kemiskinan yang dibangun dari rumah-rumah trailer yang ditumpuk satu sama lain. Dia menghabiskan waktu luangnya sebagai "Gunter" (pemburu telur), masuk ke OASIS sebagai avatar (karakter virtual) bernama Parzival. Parizival membaca jurnal Halliday's Almanac, dan meneliti secara rinci budaya pop 1980-an, terutama video game klasik dan film. Budaya pop dan kegiatan yang Halliday sukai. Suatu hari, ia menyadari bahwa kunci pertama terletak di Ludus, dunia virtual yang sama dengan sekolah menengah online-nya sendiri, dalam penciptaan kembali modul Dungeons $\&$ Dragons Tomb of Horrors. Dia bertemu Art3mis, seorang gunter dan blogger wanita terkenal yang telah menjelajahi tempat itu, dan maju lebih jauh melebihi Art3mis. Art3mismerupakan karakter atau identas virtual yang popular di OASIS ketika dia mengalahkan kecerdasan buatan atau Artificial Intelligent (AI) Acererak di video game Joust. Parzival mememenangkan game Quest pertama dari Halliday dan dianugerahi Kunci Tembaga, sehingga muncul di "Papan Skor". Ini menjadi perhatian dunia pertama Parzival di dunia OASIS.

Parzival menyelesaikan puzzle Copper Gate dengan berteleportasi ke planet Middletown, bermain melalui video game Dungeons of Daggorath dalam rekreasi rumah orangtua Halliday dan kemudian memerankan karakter Matthew Broderick dalam film WarGames. Art3mis membersihkan gerbang tak lama setelah itu, seperti halnya sahabat Wade, Aech. Ketenaran Wade memungkinkannya untuk mencari nafkah dengan mendukung produk virtual. Ini juga membawanya menjadi perhatian khusus Nolan Sorrento, kepala operasi di Innovative Online Industries (IOI). IOS meruapakan sebuah perusahaan multinasional yang bertekad pada penemuan telur Paskah untuk mengambil kendali atas OASIS dan untuk mendapatkan keuntungan secara global. Ketika Wade menolak untuk bergabung dengan IOI, Sorrento mencoba membunuhnya dengan meledakkan tumpukan tempat tinggal Wade, membunuh bibinya dan menyamarkan ledakan itu sebagai kecelakaan laboratorium.

Wade melarikan diri dan pindah ke Columbus, Ohio (kota kelahiran GSS dan IOI), di mana ia berbaring rendah, dengan asumsi nama samaran Bryce Lynch dan 
tinggal di apartemen anonim yang dirancang untuk pengguna OASIS hardcore. Wade akhirnyamelakukan aliansi dan berkelompok dengan Aech, Art3mis, serta Daito dan Shoto (duo gunter Jepang yang juga mendapatkan Copper Key). Pada tahap kedua, Art3mis akhirnya menemukan Kunci Jade pertama kali. Aech, yang merupakan pemain kedua yang menemukan Jade Key dan memberikan petunjuk yang membawanya ke planet Frobozz di mana ia memecahkan rekreasi permainan petualangan teks Zork.

Parzival akhirnya juga mendapatkan Jade Key dan berhasil membuka Jade Gate. Menggunakan pengetahuannya tentang permainan atau games "Rush", ia memperoleh Crystal Key (kunci ketiga) di planet Syrinx (bintang merah menjadi simbol Federasi Matahari di lagu "2112").Setelah memainkan games "Discovery", pada gerakan ketiga dari lagu itu, menemukan petunjuk tentang persyaratan untuk membuka gerbang terakhir yaitu gerbang kristal (Crystal Gate). Ketika ia mengirim pesan ke Art3mis, Aech, dan Shoto dengan cara memecahkan petunjuk Quest ketiga, Sorrento mengakhiri upaya mereka untuk membuka gerbang ketiga dan masuk ke Kastil Anarok (avatar dari Halliday). Selanjutnya, Wade memanipulasi identitas virtualnya untuk ditangkap IOI. Sementara di dalam IOI, ia mencuri kata sandi IOS dan mengunakannya untuk meretas ke dalam jaringan intranet IOI. Disana ia memperoleh banyak informasi, termasuk rekaman pembunuhan Daito. Informasi ini juga mencakup upaya serta rencana untuk memaksa Shoto dan Art3mis bekerja pada IOI dalam kehidupan nyata. Termasuk rencanaakan membunuh mereka di akhir kontes (IOI sendiri tidak tahu siapa Aech karena dia menggunakan nama samaran). Setelah melarikan diri dari IOI, Wade membagikan informasinya kepada temantemannya dan mempublikasikan pada semua kumpulan avatar untuk melakukan perlawanan kepada IOI dengan menyerbu IOI secara bersama-sama. Mereka diinterupsi oleh Ogden Morrow, yang menawarkan mereka tempat yang aman di rumahnya di Oregon. Wade memenuhi kehidupan nyata Aech dan Ogden, tetapi tidak dengan Art3mis dan Shoto, yang sudah terhubung ke pod Ogden.

Pada hari pertempuran, terjadi perkelahian besar-besaran di antara para seluruh avatar yang berada di OASIS. Parzival menggunakan mecha Leopardon (disertai oleh Minerva X Art3mis, Gundam Aech, dan Raideen Shoto) untuk bertarung melawan Mechagodzilla Kiryu dari Sorrento, meskipun avatar Shoto terbunuh dan Leopardon dihancurkan selama pertarungan. Parzival kemudian menggunakan kartu as di lengan bajunya: perangkat yang bisa mengubahnya menjadi Ultraman. Dengan kekuatan ini, dia benar-benar menghancurkan mekanisme Sorrento dan membunuh avatarnya. Parzival dan teman-temannya membuka gerbang, di mana Sixers menggunakan artefak yang disebut Cataclyst untuk menghancurkan kastil dan semua avatar di area yang luas.

Parzival bertahan karena memiliki kuartal Pac-Man memberinya kehidupan ekstra (bonus kehidupan - life bonus yang diberikan karakter The Currator pada saat memenangkan taruhan dengannya). Ketika memasuki Crystal Gate, dia mengumumkan bahwa jika dia menang dia akan berbagi kekayaannya dengan tiga temannya. Dengan Sorrento dan Sixers di belakangnya, Parzival memainkan Tempest, role-play King Arthur dan berbagai karakter dalam Monty Python dan Holy Grail, dan mengambil telur Paskah dalam Adventure. Kemenangannya memberinya kendali atas OASIS, termasuk kemampuan untuk "membunuh" avatar musuh-musuhnya, membangkitkan kembali teman-temannya, dan sebuah Tombol Merah Besar yang dapat mematikan OASIS selamanya. Pada akhir plot, Sorrento ditangkap karena pembunuhan Daito dan karena bersekongkol untuk membunuh Wade dan teman-teman lainnya. Kembali di Oregon, Wade dan Art3mis (nama aslinya adalah Samantha) bertemu langsung dan menjalin hubungan mereka. Mereka berdua bersama teman-temannya melakukan sebuah aturan penggunaan OASIS, yaitu menutup OASIS secara berkala dan sementara agar manusia tetap dapat melakukan aktifitas sesungguhnya di dunia nyata. 
Berikut ini merupakan karakterkarakter yang terdapat dalam film: Wade Owen Watts, James Donovan Halliday, Aech, Ogden "Og" Morrow, Daito, Shoto, dan Nolan Sorrento.

Wade Owen Watts a.k.a. Parzival sebagai karakter utama, seorang anak yatim dari "Stack" di sekitar kota metropolitan Oklahoma City.Orangtuanya (ayahnya menjadi pencuri dan ibunya seorang pelacur yang kecanduan narkoba) telah meninggal. Wade menamai karakter OASIS-nya Parzival yaitu ksatria Arthurian terlibat dalam pencarian untuk cawan suci, dan mendedikasikan hidupnya untuk menemukan telur Paskah James Halliday. Dia berusia 18 tahun ketika dia menemukan Kunci Tembaga.

James Donovan Halliday a.k.a. Anorak sebagai Pencipta OASIS. Seorang penggemar berat budaya tahun 1980-an, ia mengumumkan dalam surat wasiatnya rencananya untuk meninggalkan seluruh kekayaannya kepada siapa pun yang dapat menemukan telur Paskah yang disembunyikannya di OASIS. Karakternya awalnya terinspirasi oleh Willy Wonka yang oleh Cline digambarkan sebagai "orang kaya yang eksentrik yang mengadakan sayembara fantastis". Cline menggunakan kepribadian Howard Hughes dan Richard Garriott, dan menempatkan tahun kelahiran Halliday hampir sama dengan tahun kelahirannya sehingga minat budaya pop-nya akan bertepatan dengan Cline "dan geek uber paruh baya lainnya yang saya kenal".

Aech (diucapkan seperti huruf HCh.

33) adalah sahabat terbaik Wade, sesama gunter, dan juga saingan dalam pencarian menemukan telur. Spesialisasi Aech adalah dalam game PvP dan first-person shooter, dan merupakan salah satu pejuang top di OASIS. Meskipun avatar Aech adalah atlet pria heteroseksual Kaukasia atletik, Aech dimainkan oleh seorang lesbian AfrikaAmerika bernama "Helen Harris", yang dibesarkan di Atlanta, Georgia.

Art3mis seorang gunter dan blogger wanita terkenal. Wade memiliki sangat tertarik dan suka denganavatar ini, tetapi hal ini diperumit oleh persaingan mereka dalam mencari telur. Samantha, karakter sesungguhnya memilih nama avatarnya yaitu
Art3mis berasal dari dewi perburuan Yunani. Seperti karakter lainnya, Cline berbasis Art3mis pada dirinya sendiri dan Geeks lainnya, baik pria maupun wanita. Nama aslinya adalah "Samantha Evelyn Cook" dari Vancouver, British Columbia dan dia memiliki noda permanen di wajahnya.

Ogden "Og" Morrow a.k.a. Og memiliki karakter yang hebat dan kuat: Rekan pencipta OASIS dan sahabat James Halliday. Mereka mendirikan perusahaan permainan video Gregarious Games, di mana ia akan menangani operasi bisnis, dan yang kemudian akan menjadi Gregarious Simulation Systems (GSS), perusahaan yang meluncurkan OASIS.Penampilan dan kepribadiannya digambarkan sebagai "persilangan antara Albert Einstein dan Sinterklas". Khawatir bahwa orang-orang menggunakan OASIS untuk melarikan diri dari kenyataan, ia berhenti dari GSS dan bekerja pada perangkat lunak untuk pendidikan dengan istrinya (Kira) hingga istrinya meninggal. Hubungannya dengan Halliday memburuk, dan kedua pria itu tetap terasing sampai sebelum kematian Halliday, ketika dia dipercaya untuk memastikan perburuan itu berjalan lancar dan tanpa adanya kecurangan. Ogden tinggal di Oregon dan memiliki satu set konsol OASIS canggih dan mampu memantau semua orang di OASIS, bahkan di ruang obrolan pribadi. Dia jarang muncul di depan umum, dan hanya muncul di OASIS setahun sekali pada hari ulang tahunnya, di mana dia mengasumsikan avatar dari Great and Powerful Og. Karakter dan hubungan Ogden dengan Halliday diilhami oleh Steve Jobs dan Steve Wozniak, dengan Morrow lebih seperti Jobs sebagai "pemimpin teknologi karismatik", sementara nama avatarnya jelas terinspirasi oleh Wizard of Oz.

Daito merupakan salah satu dari dua gunter Jepang yang naik ke puncak papan skor di awal perburuan, bekerja dalam tim dengan "saudara" Shoto. Mereka lebih dekat ke Parzival, dan bekerja bersama dalam pencarian yang tidak terkait dengan perburuan. Mereka didasarkan pada Otaku: Geeks Jepang yang menikmati film dan anime, serta hikikomori: orang yang hidup sebagai petapa di dalam rumah keluarga 
mereka. Nama asli Daito diturunkan menjadi "Toshiro Yoshiaki" setelah dia dibunuh oleh IOI.

Shoto digambarkan berkarakter yang kedua dan yang lebih muda dari gunter Daito, keduanya bekerja sebagai tim dalam pencarian mereka untuk telur. Nama asli Shoto adalah "Akihide Karatsu". Setelah kematian rekannya, Shoto berkolaborasi dengan Art3mis, Aech, dan Wade untuk menyelesaikan perburuan.

Nolan Sorrento memiliki posisi Kepala operasi di Innovative Online Industries (IOI), perusahaan multinasional yang berfungsi sebagai penyedia layanan Internet untuk sebagian besar dunia, dan yang berencana untuk mengambil alih dan menguasai OASIS. Sorrento didedikasikan untuk mencari telur Paskah Halliday. Nama avatar-nya adalah IOI-655321, merupakan nomor karyawannya. 16 karyawan IOI di divisi tersebut dijuluki Sixers, merupakanenam digit angka karyawan mereka juga dimulai dengan angka 6.Cline (penulis buku yang diadopsi jadi film ini) mengatakan bahwa dia memberi nama Sorrento yaitu Nolan Bushnell, pendiri perusahaan video game Atari, dan berkata, "Bukannya aku pikir Nolan sebagai orang jahat, atau apa pun. Tetapi sebagai tribute atau penghargaan".

Penelitian dengan metode narrative analysis (Lacey, 2017) ini mengidentifikasi plot film Ready Player One dengan mengamati semua unsur fisik. Setelah mengidentifikasi, selanjutnya memahami cerita yang disajikan kepada khalayak (penonton). Unit analisis dalam riset ini yaitu:

a) Story, cerita film

b) Plot, alur atau struktur film

c) Karakter, tokoh dalam film.

Metode analisis naratif yang digunakan adalah model narrative abstract yang memiliki 8 struktur sebagai berikut:

1. The Quest (misi, pencarian)

2. Redemption (penebusan/penyelamatan)

3. Journey to Another World (perjalanan menuju kematian/kehidupan baru)

4. The Beast Transformed by Love (penjahat yang berubah karena cinta)

5. The Solving of Riddles (mengatasi tekateki/misteri)

6. The "Bitter-Bit" (kepahitan yang tersisa)

7. The Stranger Savior (penyelamat asing)

8. The Rise and Fall (kebangkitan dan kejatuhan)

Metode analisis naratif film ini merujuk pada teori Film di buku Narrative and genre: Key concepts in media studies (Lacey, 2017)

\section{HASIL DAN PEMBAHASAN}

Berikut potongan gambar serta tabel analisis naratif pada film Ready Player One:

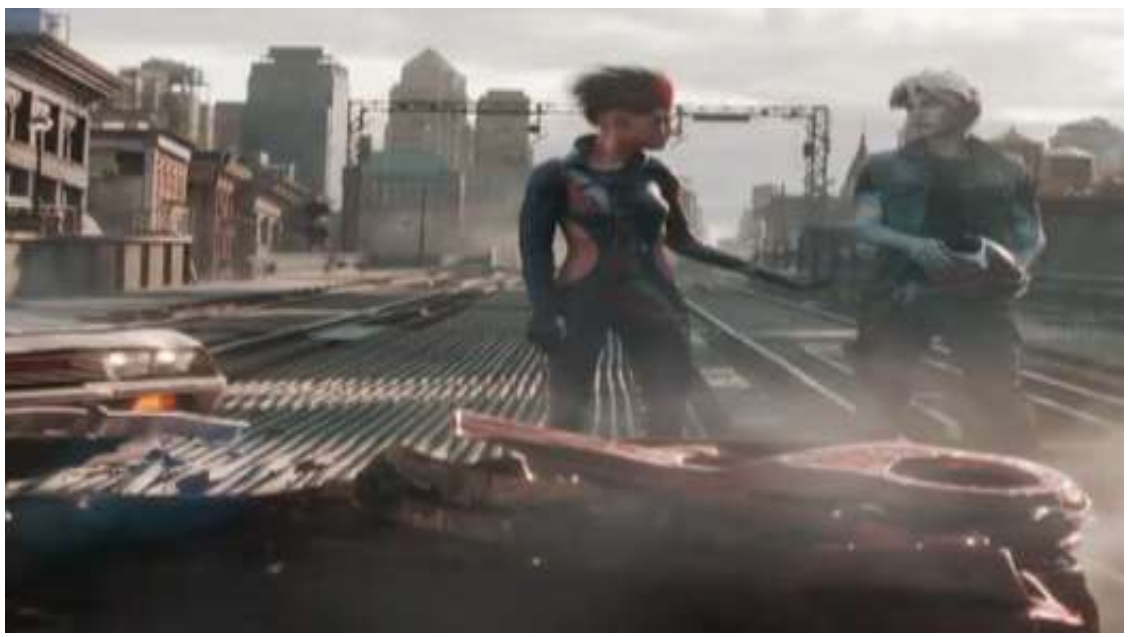

Gambar 2. Adegan struktur The Quest \& Redemption (sumber: olahan peneliti) 
Tabel 1. Tabel Analisis Struktur The Quest \& Redemption

\section{Struktur The Quest \\ Unit Analisis Story}

Sesaat sebelum meninggal, James Halliday (pemilik dan pencipta dunia baru bernama OASIS) memberikan sebuah tantangan atau misi bagi warga di dunia maya yaitu mendapatkan Telur Paskah (Easter Egg). Siapapun yang mendapatkan telur paskah tersebut akan menguasai dan memiliki dunia digital OASIS, yang berarti mewarisi kekayaan James Halliday milyaran dollar. Untuk mendapatkan telur paskah itu, pemburu harus memiliki tiga kunci lebih dulu (Cooper, Jade, Crystal). Masing-masing kunci memiliki tahapan misi yang berbeda-beda. Tiga kunci tersembunyi membuka tiga gerbang rahasia yang merujuk pada 3 kunci yang diperlukan untuk memasuki Kastil Anorak, rumah dari avatar Halliday, Anorak.

Unit Analisis Plot

Film bergerak sporadis, diawali dengan gambaran kehidupan manusia di dunia nyata pada tahun 2045. Alur kemudian meloncat ke dunia maya dengan adanya perburuan telur paskah, tantangan dari James Halliday. Terdapat 3 plot besar yang sangat menonjol perbedaannya sesuai misi (Quest), yaitu plot pada misi membuka gerbang pertama, gerbang kedua dan gerbang ketiga yang terakhir hingga memasuki kastil Anarok. Tiap gerbang karakter-karakter yang mengikuti misi (Quest) dari Haliday harus melakukan hal sesuai petunjuk berupa poem atau puisi, ada 3 puisi untuk tiap gerbang yaitu Original Poem, The Limerick, dan The Quatrain.

$\underline{\text { Unit Analisis Karakter }}$

Karakter utama film ini adalah Wade Watts yang memiliki avatar di dunia mayar bernama Perzival serta beberapa kawan baiknya. Karakter ini memecahkan 3 teka-teki sebagai misi memenangkan lomba. Ada 3 misi dengan masuk 3 gerbang rahasia yang membutuhkan 3 kunci berbeda yaitu kunci cooper untuk gerbang pertama, kunci jade untuk gerbang kedua dan terakhir kunci crystal untuk gerbang ketiga. Untuk mendapatkan masing-masing kunci karakter Perzial harus menyelesaikan misi yang berbeda dengan petunjuk dari poem atau sajak yang diberikan oleh karakter avatar Haliday di dunia virtual yaitu Anarok.

\section{StrukturRedemption}

Unit Analisis Story

Pada aspek Redemption, kisah film ini menceritakan sebuah perjuangan besar Wade Watts dengan kelompoknya melawan dominasi perusahaan IOI yang ingin menguasai dunia OASIS.

Unit Analisis Plot

Alur berjalan penuh loncatan, flash back dan flash forward, dengan akhir masa sekarang (2045) dan di dunia nyata.

Unit Analisis Karakter

Karakter utama dalam struktur redemption ini tetap Wade Watts, dengan tokoh antagonis CEO perusahaan IOI, Nolan Sorento

Tabel 2. Tabel Analisis Struktur Journey to Another World\&The Beast transformed by love

\section{Struktur Journey to Another World}

Unit Analisis Story

Pada struktur ini, kisahnya cukup jelas dan mudah diikuti, yaitu bagaimana warga dunia nyata bisa berseluncur ke dunia yang lain, yaitu dunia maya. Lebih jauh dari itu, warga di dunia maya pun dapat mengunjungi dunia baru atau dunia impian bernama OASIS, bahkan berlomba untuk menguasainya dan mencapai tujuan ke Castle Anorak, rumah tinggal almarhum James Halliday.

Unit Analisis Plot

Alur perjalanan karakter utama dari satu dunia ke dunia lain ini juga digambarkan dengan lompatanlompatan flash back dan flash forward. Perjalanan ke dunia lain juga ditampakkan saat terbukanya gerbang pertama sampai ketiga dengan kunci-kunci tembaga, jamrud, dan kristal.

Unit Analisis Karakter

Dalam perjalanan ini tokoh utama ditemani beberapa kawan dalam kelompok satu perjuangan, beberapa pesaing dalam lomba, dan beberapa tokoh yang menjadi sosok antagonis. 


\section{Struktur The Beast Transformed by Love}

Unit Analisis Story

Film ini tidak menggambarkan struktur transformasi the beast menjadi the good one. Memang ada sedikit kisah mirip cinta antara Perzival (avatar dari Wade Watts) dengan seorang gadis pemburu telur paskah yang awalnya adalah pesaing (art3mis), namun kemudian menjadi sekutunya.

Unit Analisis Plot (tidak ada)

Unit Analisis Karakter

Karakter tidak berkembang alias statis, dari awal sampai akhir sama, yaitu tokoh protagonist berjuang melawan tokoh protagonist. Tidak ada si jahat menjadi baik atau sebaliknya.

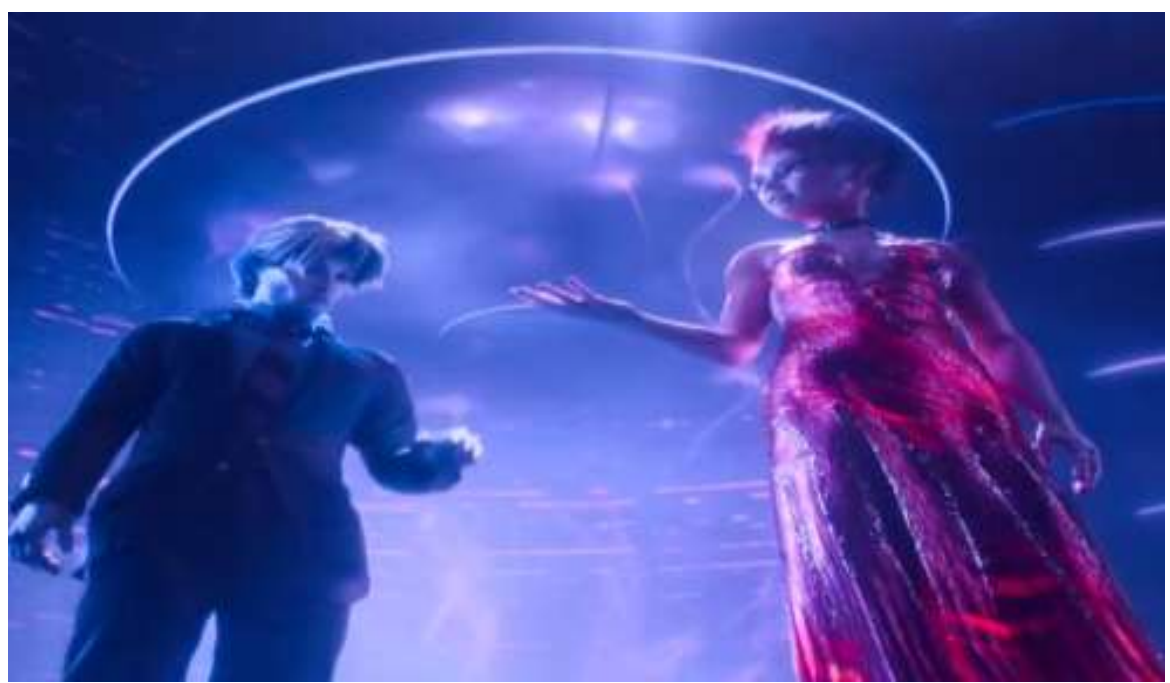

Gambar 3. Adegan struktur The Beast transformed by love (sumber: olahan peneliti)

\section{Tabel 3. Tabel Analisis Struktur The Solving of Riddles\&The "Bitter-Bit"}

\section{Struktur The Solving of Riddles}

Unit Analisis Story

Untuk menemukan Telur Paskah, diperlukan tiga kunci untuk membuka tiga gerbang yang tersebar di seluruh OASIS. Setelah tiga gerbang terbuka, masih ada beberapa tantangan dengan tingkat kesulitan yang berbeda. Tantangan-tantangan inilah yang menjadi ruh dari struktur Solving the Riddles.

Unit Analisis Plot

Di bagian ini film memasuki adegan yang bisa disebut sebagai race atau perlombaan, karena para pemburu telur paskah berusaha keras untuk memecahkan teka-teki dan misteri dari warisan Halliday. Mereka bersaing keras satu sama lain.

Unit Analisis Karakter

Karakter tetap, hanya di sini ditonjolkan karakter non-human, dalam hal ini beberapa petunjuk untuk memecahkan 3 teka-teki Halliday berupa poem atau sajak untuk bisa masuk 3 pintu gerbang rahasia dengan 3 kunci berbeda (cooper, jade,crystal). yaitu Original Poem dan The Limerick, serta the Quatrain, yang disembunyikan sampai Gerbang Pertama dibuka.

Original Poem adalah sajak atau puisi pertama yaitu:

Three hidden keys open three secret gates

Wherein the errant will be tested for worthy traits

And those with the skill to survive these straits

Will reach The End where the prize awaits

The Limerick adalah Poem kedua, yaitu:

The Copper Key awaits explorers

In a tomb filled with horrors

But you have much to learn 


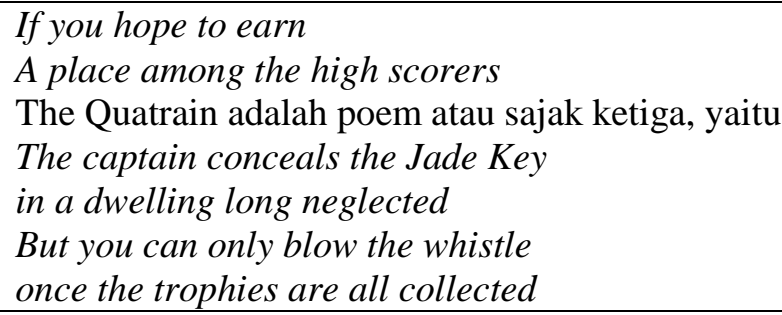

\section{Struktur The "Bitter-Bit"}

Unit Analisis Story

Escape from Reality atau pergi meninggalkan kenyataan hidup. Dunia adalah tempat yang digambarkan sangat buruk dan tidak menyenangkan pada cerita film ini. Ketergantungan dengan teknologi yang sangat berlebihan. Penguasa teknologi mendominasi kehidupan sosial, ekonomi dan budaya di masyarakat dunia.

\section{Unit Analisis Plot}

Aspek "bitter-bit" ini muncul di beberapa bagian, sejak di awal, di tengah, hingga di akhir film. Unit Analisis Karakter

Tidak ada Karakter dalam struktur "bitter-bit"

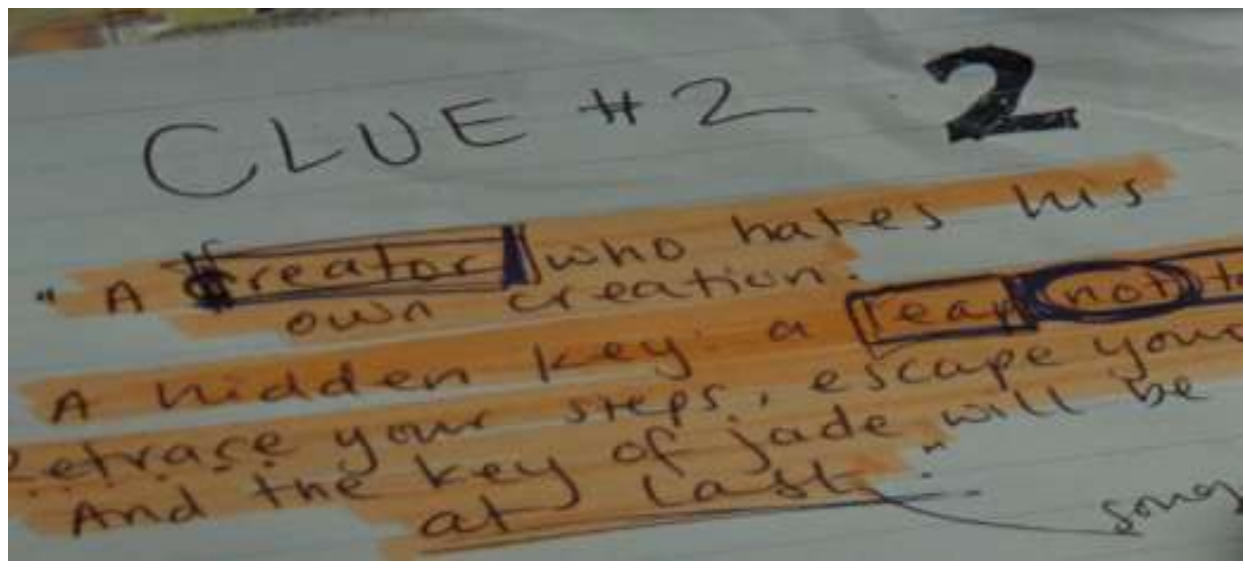

Gambar 4. Adegan struktur Solving the Riddles (sumber: screencapture film - olahan peneliti)

Tabel 4. Tabel Analisis Struktur The Stranger Savior\&The Rise and Fall

\section{Struktur Stranger Savior}

Unit Analisis Story

Pada cerita keseluruhan penyelamat asing adalah sang Kurator (The Curator) yaitu karakter yang menjaga dan memberikan berbagai informasi di perpustakan virtual Haliday. Tiap akan menyelesaikan petunjuk masing-masing poem, Parzival dan teman-temannya harus melihat dan memahami petunjuk tersebut di perpustakaan virtual milik Haliday

Unit Analisis Plot

Penyelamat asing muncul pada beberapa adegan terutama pada digital archive dari kehidupan Halliday. Plot-plot cerita yang flash back dan flash forward banyak menunjukkan penolong atau penyelamat asing itu adalah The Curator.

Unit Analisis Karakter

The Curator atau Ogden "Og" Morrow adalah ko-kreator OASIS dan merupakan teman terbaik James Halliday. Dia adalah salah satu dari sedikit orang di dunia yang kaya dan mampu menggunakan kemewahan dan kekayaannya untuk membantu orang lain. Penampilan dan kepribadiannya digambarkan sebagai gabungan antara Albert Einstein dan Santa Claus. Meskipun kaya, dia rendah hati dan menghormati permainan temannya (Halliday) yang sudah meninggal dan perburuan telur yang dilakukan orang-orang di OASIS. Dia akhirnya berhenti dari pekerjaannya di Gregarious Simulation Systems, khawatir bahwa orang menggunakannya untuk melarikan diri dari kenyataan. 


\section{Struktur The Rise and Fall}

Unit Analisis Story

Pada intinya, film ini lebih banyak bercerita tentang sebuah kebangkitan. Bila ada yang disebut kejatuhan, mungkin itu adalah kejatuhan perusahaan IOI yang kalah dalam pertarurngan mendapatkan telur paskah atau warisan Halliday. Kisahnya adalah kebangkitan para warga dunia maya untuk menguasai dunia baru dunia impian OASIS.

Unit Analisis Plot

Alur sangat jelas, diawali sebuah tantangan bersifat misteri atau teka teki, kebangkitan kelompok kelas bawah untuk meraih kekuasaan, dan seteah melalui berbagai perjuangan, mengatasi tantangan, mereka berhasil.

Unit Analisis Karakter

Wade Watts dan kelompoknya menjadi mereka yang bangkit dan menang, sementara para CEO perusahaan IOI adalah mereka yang jatuh. Karakter antagonis dari IOI ditangkap pihak berwajib dan masuk penjara.

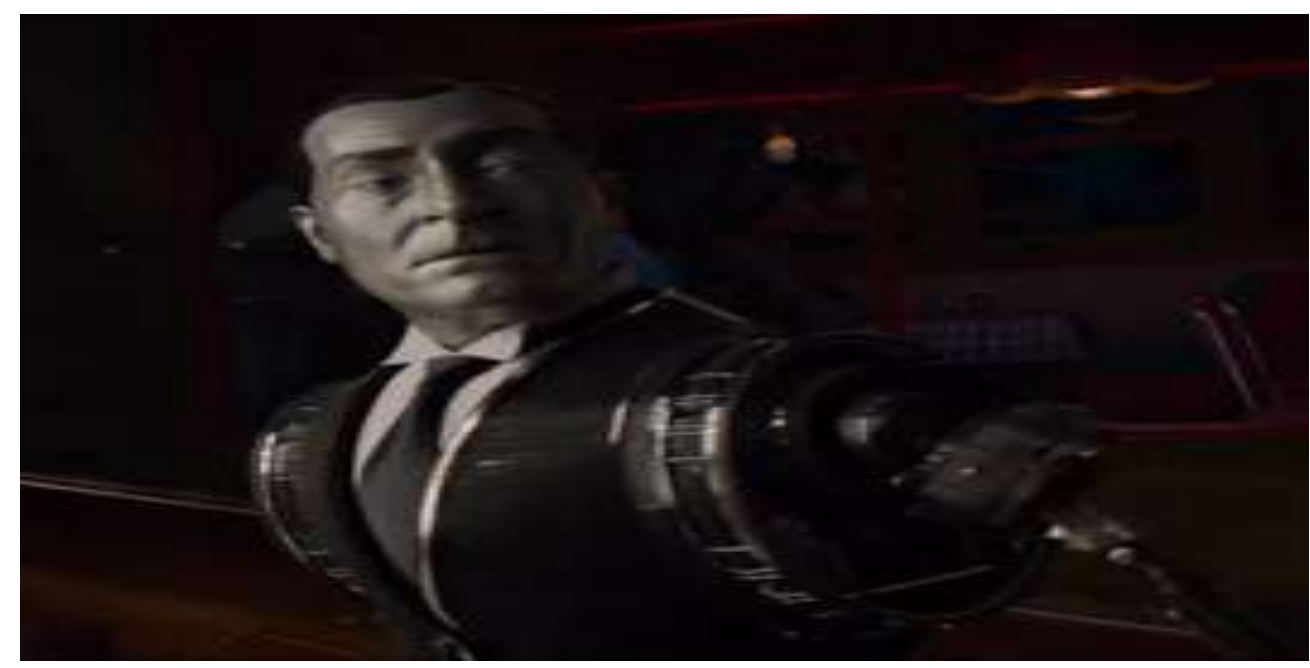

Gambar 5. Adegan struktur Stranger Savior (sumber: screencapture film - olahan peneliti)

Film Steven Spielberg ini adalah orientasi pembangunan dunia, baik visual maupun temporal. Penggambaran teknologi sehari-hari pada tahun 2045, seperti layanan Pizza-drone yang mengirimkan layanan antar pizza ke konsumen; papan reklame video yang sangat besar yang divisualisasikan secara 3 dimensi. Di film tersebut memberikan gambaran fiksi masa depan sebagai realitas dan realitas virtual yang dijalankan oleh masyarakat pada masa tersebut.Daerah pemukiman aktor utama yaitu Stacks, kota Columbus seperti gambaran pada umumnya dunia yang suram dan tidak teratur, daerah pinggiran yang kumuh. Masyarakat di tempat tersebut digambarkan melakukan pelarian dari kehidupannya nyatanya (escape from reality) melalui headset Virtual Reality (VR). Semua lari dari kehidupannya nyatanya masuk ke dunia tanpabatasyaitu OASIS, sebuah metavisi luas dari pengalaman virtual di mana orang dapat menikmati segala sesuatu.Mulai dari permainan yang paling diminati(games) hingga melakukan pendakian Gunung Everest dengan Batman (tokoh pahlawan super yang disukai). 


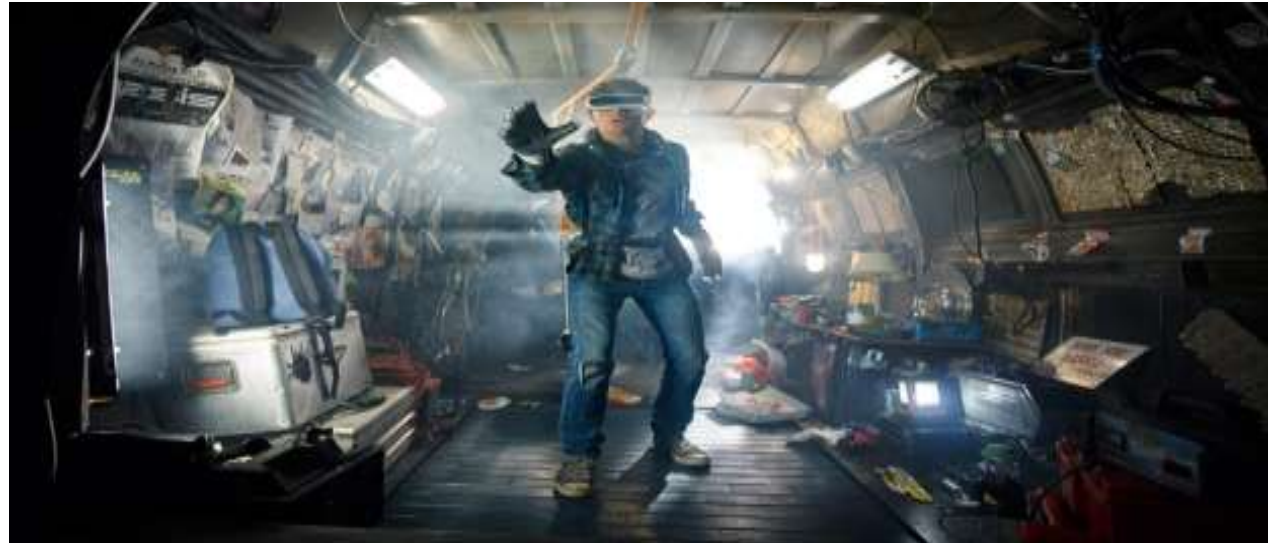

Gambar 6. Wade Watts menggunakan Kacamata VR untuk masuk ke dunia OASIS (sumber: screencapture film - olahan peneliti)

Film Spielberg telah banyak membahas tentang topik-topik yang menjadi perdebatan sebelumnya seperti terorisme, perbudakan, Pentagon Papers, Shark. Tetapi baru pada film ini Spielberg memberikan gambaran yang sangat detil tentang kebangkitan, tidak ada hal yang tidak mungkin, pembelaan, penghinaan dan amarah "sebenarnya" seperti pada subjek film ini.Film yang menggambarkan tentang pertandingan (dalam kemasan permainan/games), dengan adanya petunjuk yang harus dipecahkan. Kebangkitan dari penindasan dan dominasi penguasa, yang terjadi di dua dunia sekaligus secara bersamaan. Dunia nyata (Reality World) dan Dunia Virtual (Virtual World).

Dan bukan hanya eksplorasi video game. Film yang diadopsi dari Novel SciFiction "Ready Player One," yang ditulis oleh Mr. Cline dan Zak Penn ini menggambarkan bagaimana penonton terjun ke semangat penggemar video games. Penggambaran pria cerdas yang mengasihani diri sendiri hingga techno-mitologi pada film ini. Steven Spielberg adalah seorang penggila digital dan sineas kawakan berani melangkah lebih jauh dari kebanyakan pembuat film (sineas) dalam mengeksplorasi kemungkinan estetika dari suatu bentuk yang sering diabaikan dan disalahpahami oleh masyarakat.

Dibantu oleh sinematografernya, Janusz Kaminski, dan desainer produksi film Adam Stockhausen, Spielberg mengubah lanskap virtual yang luas dari pertarungan avatar menjadi taman hiburan pop-culture yang ramai, museum interaktif, hiburan akhir abad 20 dan awal abad ke-21, labirin yang disesuaikan oleh selera pengguna virtual reality itu sendiri.

Hasil analisis menunjukkan bahwa film ini sebetulnya film fiksi sebagaimana umumnya, dengan kisah khayalan dan tokohtokoh khayalan pula. Film bergenre fiksi ilmiah ini dapat juga disebut drama, karena mengandung muatan konflik di dalamnya. Yang menjadikannya istimewa adalah pilihan latar waktu dan latar sosio-kultural -yaitu tahun 2045 dan dunia digital- yang dalam dekade ini menjadi perhatian banyak ilmuwan dan teoretikus/ilmuwan sosial, komunikasi, dan new media, seperti Foucault, Giddens, Baudrillard, dan Castells.

Dengan pisau bedah new media, film ini berhasil menggambarkan masa depan manusia, setidaknya di tahun 2045, yaitu dunia yang dikitari mesin-mesin otomatis dan manusia-manusianya suka melarikan diri ke dunia yang lain, yaitu dunia digital. Pisau bedah subjektivitas dan identitas Foucault juga menampakkan potensi terjadinya satu sosok manusia memiliki dua atau lebih identitas, yaitu identitas yang nyata dan (beberapa) identitas yang semu. Fenomena ini bahkan sudah berlangsung sekarang dengan maraknya aktivitas komunikasi dan eksistensi diri di media sosial seperti Instagram, youtube, facebook, dan lain-lain.

Di samping persoalan teknologi dan isu di dunia digital, kisah film ini juga masih mengusung persoalan perlawanan sosial dan perebutan kekuasaan, isu-isu klasik yang terus menerus berulang di setiap zaman, seperti disinggung oleh Giddens (dominasi 
dan hegemoni)(Mouffe, 2014). Bahkan, teori Foucault tentang Power and Knowledge juga mewujud dalam film ini, bahwa yang memiliki pengetahuan akan meraih kekuasaan; dan sebaliknya yang berkuasa akan dengan mudah mendapatkan pengetahuan(Elden \& Crampton, 2016).

Konsep konstruksi realitas Berger juga tergambarkan dengan baik melalui adegan-adegan dan visual yang meyakinkan, sehingga penonton bisa mengira tokoh Wade Watts di dunia nyata adalah semu, dan sebaliknya avatarnya yang bernama Parzival adalah identitas riil. Inilah keberhasilan konstruksi realitas Berger dalam film ini(Kjærgaard, Morsing, \& Ravasi, 2011). Sementara, konsep hiper-realitas Baudrillard menggarisbawahi keberhasilan konstruksi realitas dalam film, dengan membuat pemirsa film merasakan dan meyakini seolah-olah pertandingan dalam pencarian telur paskah dan tiga kunci itu nyata adanya(Der Derian, 2009). Ini dimungkinkan karena penggambaran realitas yang berlebihan di dunia digital dalam film.

Sebagaimana kebanyakan film Spielberg yang dilatarbelakangi minatnya di dunia sains (E.T, A.I., Jurassic Park), unsur drama dan sisi kemanusiaan di film ini tidak diabaikan. Konflik dalam film yang membuat tiap karakter menonjol, apakah karakter itu statis (tak mengalami perubahan) maupun yang mengalami perkembangan, merupakan anasir penting yang mewarnai film fiksi ilmiah ini. Konflik dibangun secara masuk akal, menghindarkan kesan penonton bahwa film ini tak lebih dari sekadar pemfilman sebuah game (permainan digital) yang sedang popular.

Kompleksitas berbagai elemen yang diramu dalam sebuah tontonan film ini dikelola dengan baik sehingga tidak saling bertabrakan dan justru saling mendukung. Elemen kemajuan teknologi di abad ini (abad 21, tepatnya di latar waktu tahun 2045), dipadu dengan naluri manusia yang bersifat sosial-politik, yaitu ingin memenangkan pertarungan atau meraih kekuasaan. Perpaduan ini melahirkan impresi (kesan) pada penonton bahwa kapanpun zamannya, bagaimanapun kemajuan teknologinya, isu klasik hegemoni kuasa dan perlawanan terhadapnya akan selalu ada, dalam bentuk dan wadah yang berbeda.

Sementara, identitas nyata dan identitas semu ditampilkan secara seimbang dalam cerita, dimana beberapa tokoh utama muncul berselang-seling sebagai manusia biasa dan sebagai avatarnya. Pergulatan mereka adalah pergulatan di dunia nyata yang digambarkan penuh kerumitan hidup, kesulitan ekonomi, dominasi teknologi. Juga, pergulatan di dunia digital, dimana mereka bertarung memperebutkan sebuah dunia idaman, sebuah oasis di tengah kesulitan, dunia yang digambarkan sempurna.

Pesan moral yang bisa disimpulkan pada film ini adalah bahwa manusia bisa melakukan Escape from Reality, atau menyingkir untuk beberapa saat dari kenyataan hidup.Ketika cerita dimulai, Halliday (pencipta OASIS) sudah mati, tetapi di suatu tempat dalam ranah imajinasinya yang murni, dia telah menyembunyikan Telur Paskah. Telur Paskah ini adalah tiket emas, siapa saja yang menemukannyaakan mewarisi OASIS, dan bisnis triliunan dolar yang dalam dunia OASIS. Film ini menggambarakan pertarungan virtual dan realitas 2 orang yaitu Wade Watts dan Nolan Sorento.

Keduanya memiliki keinginan dan tujuan yang berbeda guna memenangkan pertarungan mendapatkan Telur Paskah. Nolan Sorento sebagai penguasa IOI perusahaan digital yang mempunyai produkproduk digital dalam dunia OASIS ingin menguasai penuh OASIS agar dapat menjadi penguasa tunggal di dunia virtual maupun nyata. Sedangkan Wade Watts bersama teman-temannya menjadi penggerak sosial untuk melakukan perlawanan hegemoni dan dominasi IOS di dunia virtual maupun dunia nyata.

Kekacauan terjadi ketika dunia online dan offline (nyata dan virtual) mulai berbaur satu urutan. Scene akhir film inimenunjukkan Nolan pada dunia nyata mengejar kelompok Wade pada sebuah mobil Van. Didalam mobil Van terlihat Wade menggunakan kacamata VR sedang berada di dunia virtual (OASIS).Terlihat pada scene ini setiap benturan dan guncangan yang terjadi secara nyata juga terjadi di dunia virtual. Tapi setidaknya untuk sementara waktu, kedua 
domain itu disimpan dengan sangat ketat dan berseni terpisah - tidak hanya oleh para pemain, tetapi oleh film itu sendiri.

Kehidupan kasar dan kacau pada daerah Stack pada tahun 2045 tergambar seperti dunia nyata pada tahun 1980an, terlihat dari model pakaian dan gaya rambut hingga games-games yang ditampilkan pada film ini. Games konsol yang popular pada tahun 1980-1990an, dan bukan hanya games tetapi tokoh superhero yang popular pada jaman ituditampilkan secara apik. Pada awal film terlihatMinecraftmenjadi salah satu game paling ramai di OASIS. Pada scene perang "battle royale" atau di Planet Doom, perlawanan terhadap IOI, bisa dilihat sekumpulan pemain dengan Avatar kostum HALO (games perang).

Tokoh Batman terlihat beberapa kali dalam pertempuran maupun sebagai avatar. Harley Quinn dan Joker juga tampak berdansa di klub dansa dalam OASIS. Pada plot cerita Parzival yang mencoba memecahkan misi kedua, avatar Wade Watts ini menyamar dengan mengenakan artefak yang berupa kacamata Clark Kent (Superman). Mobil andalan Parzival bernama Delorean, kendaraan mobil yang dipakai Marty McFly dalam trilogy film"Back To the Future".

Selain itu nama sang sutradara Zemeckis dipakai sebagai nama artefak yang bisa memutar ulang waktu.Dua monster raksasa, King Kong dan T-Rex Jurrasic Park jadi penghalang peserta pada misi pertama untuk mendapatkan kunci pertama di lomba balap.Robort yang berasal dari film ikonik "Iron Giant" dibangun dan dipakai oleh sahabat Parzival, Aech.Freddy Krueger tokoh utam film "Friday the $13^{\text {th" }}$ juga menjadi salah satu avatar yang bertarung di dalam OASIS.

Gundam jadi salah satu jagoan yang paling menarik perhatian pada film ini. Daito, salah satu teman Parzival mempunya senjata Gundam yang kemudian digunakannya untuk melawan avatar Nolan Sorentto pada "Battle Royal". Film horor ikonik "The Shining" dari tahun 80-anjuga menjadi salah satu bagian penting pada film ini. Pada misi kedua, untuk mendapatkan kunci kedua, Parzival dan teman-temannyaharus menyusuri dan memecahkan teka-teki dalam arena yang dibuat berdasarkan film horor dari karya Stephen King ini.

Masih cukup banyak game dan film legendaris (tahun 1980-1990an) di film ini. Mulai dari game-game konsol Atari 2600 sampai Star Wars, dari Hello Kitty sampai Mario Kart. Film ini membawa nostalgia penonton pada imajinasi film dan games yang popular pada tahun 80-90an.

\section{SIMPULAN}

Menjawab pertanyaan dalam rumusan masalah mengenai "Bagaimana realitas nyata dan realitas digital digambarkan dalam film ini”, peneliti menemukan kesimpulan -setelah meneliti dengan metode analisis naratif- hasil sebagai berikut:

Realitas sosial dan realitas digital dalam film Ready Player One?digambarkan dengan baik, sesuai dengan teori konstruksi realitas Berger dan hiper-realitas Baudrillard, serta teori new media Castells. Narasi konflik dalam film juga mewujudkan konsep Foucault dan Giddens tentang masih terjadinya hegemoni kekuasaan, perlawanan sosial atau pertentangan kelas, dan relasi power-konwledge pada tahun 2045, seperempat abad ke depan dari sekarang. Ini menggambarkan ramalan seniman -bila sineas adalah seniman- bahwa pada abad ini (abad 21) dan abad-abad ke depan, persoalan manusia masih tetap sama, yaitu berlomba meraih kekuasaan. Bedanya dengan kemarin dan sekarang, di zaman yang akan datang, perebutan kekuasaan itu terjadi di dua alam: alam nyata dan alam digital(Steinberg \& Kincheloe, 2010).

Terjadinya perkembangan sosial yang dikontruksi oleh masyarakat pascamodern melalui berbagai medium (teknologi) baru, tidak serta-merta menjadikan adanya perubahan persoalan dalam kehidupan manusia. Sekali lagi, isu-isu sosial politik yang sama akan selalu muncul, selalu ada.

Dalam film ini, dunia nyata digambarkan sangat buruk dan tidak menyenangkan. Dunia telah dirusak oleh perang yang tak terhitung jumlahnya dan menyebabkan krisis energi. Manusiamanusianya digambarkan senantiasa dalam 
kondisi penuh kecemasan -atau apatis dan tak peduli- dan dua golongan ini menjalani pelarian yang sama: ke dunia digital. Di dunia yang baru, yang semu (digital) manusia berjuang untuk dapat menguasai dunia baru idaman yang dinamai OASIS.

Banyak orang yang ingin melupakan atau menghindari kesulitan hidup dan berbagai persoalan di dunia nyata, akan dengan mudah masuk ke alam realitas virtual (digital reality).

Saat ini tak sedikit orang melakukan pencarian identitas diri dalam game virtual, lalu terjebak oleh sifatnya yang samar. Bahkan banyak kaum muda atau biasa disebut kaum milenial membuat identitas baru yang bersifat negatif (negative identity), yaitu identitas yang dibentuk dengan mengidentifikasi dengan peran yang bertentangan dengan harapan masyarakat(Hihara, Sugimura, \& Syed, 2018), termasuk dengan menjadi karakter antagonis.

Bila diuraikan berdasarkan struktur plot (alur) dan cerita (drama, konflik), dua realitas di film ini (realitas nyata dan realitas digital) disajikan dengan jelas dan menarik. Dalam arti, penonton dengan mudah mengikuti perpindahan setting dua dunia yang beralur maju-mundur. Juga penonton dapat merefleksikan sejarah hidupnya berkaitan dengan peristiwa sosial-politik (perebutan kekuasaan, hegemoni, kekuatan pengetahuan, dan lain-lain) melalui konflik/drama perjuangan Wade Watts dan kawan-kawan.

Tidak dapat diabaikan adalah elemen teknologi, filmografi yang tidak biasa, agak menyimpang dari trend film popular. Penggunaan seni computer grafis dalam film ini menghasilkan efek-efek visual yang canggih, yang tak hanya menghibur tetapi juga mencerahkan. Dalam arti, menyaksikan film ini orang dapat belajar tentang gambaran wajah dunia masa depan, sekaligus belajar tentang potensi teknologi (khususnya computer graphic, ITC), yang dapat dimanfaatkan sebaik-baiknya dalam kehidupan sekarang.

Pada scene terakhir pada film ini menunjukkan kegiatan nyata yang dilakukan 2 karakter utama yatu Wade Watts dan
Samantha. Ketika Wade Watts dan temantemannya mempunyai kuasa penuh pada OASIS. Terdapat satu pernyataan yang penuh makna yaitu "Karena kenyataan hanya ada di dunia nyata," kata Wade, sambil memangku Samantha Evelyn Cook. Wade Owen Watts karakter di dunia nyata, Parzival di OASIS. Samantha di dunia nyata, Art3mis di dunia OASIS. Keduanya bersama tiga gunter lain disebut The High Five, mengalahkan Nolan Sorrento dari IOI, sebuah konglomerasi industri teknologi yang berambisi untuk menguasai dunia, temasuk OASIS.

Kalimat yang dinarasikan Wade sebenarnya merujuk kepada kalimat James Halliday, karakter utama dalam novel karya Ernest Cline "Ready Player One" yang diangkat ke layar lebar oleh sutradara Steven Spielberg ini. Sebuah ironi, "Meskipun menakutkan dan menyakitkan, dunia nyata adalah satu-satunya tempat di mana kalian bisa menemukan kebahagiaan yang sebenarnya. Karena, kenyataan itu nyata."

Setelah menang, dan menguasai kepemilikan perusahaan yang dibangun James Halliday, kreator OASIS yang juga konglomerat industri teknologi, Wade Watts dan kawan-kawannya memutuskan untuk meliburkan dan menutup akses ke OASIS, selama dua hari dalam seminggu. Ini bertujuan agar supaya orang-orang yang kecanduan OASIS dapat menikmati dunia secara nyata. Tidak hanyaaktif dan menghabiskan hidupnya di dunia virtual (OASIS) untuk main game hingga melarikan diri dari permasalahan kehidupan nyata.

\section{DAFTAR PUSTAKA}

Bendle, M. F. (2002). The crisis of 'identity'in high modernity. The British Journal of Sociology, 53(1), 1-18.

Castells, M. (2011). The power of identity: The information age: Economy, society, and culture (Vol. 2). John Wiley \& Sons.

Cettl, F. (2019). Staying with the paradox of Avatar: Decolonising science/fiction. Science Fiction Film \& Television, 12(2), 225-240. 
Der Derian, J. (2009). The Value of Security: Hobbes, Marx, Nietzsche, and Baudrillard. In Critical Practices in International Theory (pp. 161-178). Routledge.

Elden, S., \& Crampton, J. W. (2016). Introduction Space, knowledge and power: Foucault and geography. In Space, Knowledge and Power (pp. 1328). Routledge.

Hihara, S., Sugimura, K., \& Syed, M. (2018). Forming a negative identity in contemporary society: Shedding light on the most problematic identity resolution. Identity, 18(4), 325-333.

Ida, R. (2014). Metode Penelitian: Studi Media dan Kajian Budaya. Kencana.

Joyce, M. C. (2010). Digital activism decoded: The new mechanics of change. IDEA.

Kjærgaard, A., Morsing, M., \& Ravasi, D. (2011). Mediating identity: A study of media influence on organizational identity construction in a celebrity firm. Journal of Management Studies, 48(3), 514-543.

Lacey, N. (2017). Media, Institutions and Audiences: Key Concepts in Media Studies. Macmillan International Higher Education.

Lubenow, J. A. (2012). Public Sphere and Deliberative Democracy in Jürgen Habermas: Theorethical Model and Critical Discourses. American Journal of Sociological Research, 2(4), 58-71. https://doi.org/10.5923/j.sociology.2012 0204.02

Luqiu, L. R. (2018). Counter-hegemony: grassroots use of the Internet to save dialects in China. Journal of
Multilingual and Multicultural Development, 39(8), 663-674.

McGushin, E. (2011). Foucault's theory and practice of subjectivity. Michel Foucault: Key Concepts, 127-142.

Mouffe, C. (2014). Hegemony and ideology in Gramsci. In Gramsci and Marxist Theory (RLE: Gramsci) (pp. 178-214). Routledge.

Nony, A. (2019). Dividual Revolution: What Can Philosophy Do in the Digital Present? Cultural Critique, 105, 179198. Retrieved from https://www.jstor.org/stable/10.5749/cul turalcritique.105.2019.0179

Steinberg, S. R., \& Kincheloe, J. L. (2010). Power, emancipation, and complexity: Employing critical theory. Power and Education, 2(2), 140-151.

Taylor, D. (2014). Michel Foucault: Key Concepts. Routledge.

\section{Internet}

https://readyplayerone.fandom.com/wiki/Hall iday\%27s_Easter_Egg_Hunt (terakhir akses, 12 Agustus 2019)

https://www.imdb.com/title/tt1677720/ (terakhir akses 9 Agustus 2019)

https://www.warnerbros.com/ready-playerone (terakhir akses, 1 Agustus 2019) 